Res Publica Revista de Historia de las Ideas Políticas

ISSN: $1131-558 \mathrm{X}$

\title{
Salvador Allende: El ocaso de una modernidad plebeya
}

\author{
Oscar Ariel Cabezas ${ }^{1}$
}

Recibido: 25-02-2021 / Aceptado: 28-05-2021

Resumen. Este texto describe la figura trágica de Salvador Allende desde la pregunta por el presente. El análisis busca mostrar la relación entre el líder de la Unidad Popular y un cierto agotamiento de la modernidad socialista como programa civilizatorio. El ocaso de la modernidad, sin embargo, encontraría resistencias en el acto ético de Allende y el aura de su fantasma político cuya agencia residual se presenta como un difícil problema para la política tradicional.

Palabras clave: Salvador Allende; modernidad; acto ético; política.

\section{[en] Salvador Allende: The Decline of a Plebeian Modernity}

Abstract. This text describes the tragic figure of Salvador Allende from the question of the present. The analysis seeks to show the relationship between the leader of Unidad Popular and a certain exhaustion of socialist modernity as a civilizing program. The decline of modernity, however, would find resistance in Allende's ethical act and the aura of his political ghost whose residual agency presents itself as a difficult problem for traditional politics.

Keywords: Salvador Allende; Modernity; Ethical Act; Politics.

Sumario. 1. Introducción. 2. Entre excepcionalidady dietética (empanadas y vino tinto). 3. Desmitificación y olvido. 4. Neutralización de la experiencia plebeya. 5. La "pequeña" victoria en el interior de la derrota. 6. El ocaso moderno del Bien Común. Bibliografía.

Cómo citar: Cabezas, O. A. (2021). Salvador Allende: El ocaso de una modernidad plebeya. Res Publica. Revista de Historia de las Ideas Políticas, 24(2), 259-274.

Allende: "Mira, Régis, a mí me dijeron siempre «el compañero Allende». Hoy me dicen «el Compañero Presidente», claro está que yo peso la responsabilidad que eso significa. -R. Debray, Conversaciones con Allende (1971)

\section{Introducción}

En el interior de la revuelta por la dignidad que comenzó el 18-O del 2019, el fantasma de la memoria de Salvador Allende está hoy desplazado de los debates parlamentarios con los que se dirime el presente del país que elevó el neoliberalismo a un paradigma de desarrollo económico y cultural. La figura mitológica de Allende es la de alguien que está vivo y muerto. La paradoja de esta ausencia y, a su vez, de lo que sería una débil sobrevida de su legado en los movimientos de indignación habría que buscarla en el análisis de lo que significó la política de los consensos de la llamada transición democrática iniciada con el plebiscito de 1989. Esta política llevada a cabo por la izquierda tradicional permitió la construcción de una de las más poderosas hegemonías neoliberales en América Latina ${ }^{2}$. Esta hegemonía ha sido fracturada por la revuelta del 18-O. El resultado de la fractura ha dañado el pacto entre la sociedad civil y el Estado basado sobre todo en una sociedad orientada al emprendimiento individual y al consumo. Si la fractura en la hegemonía abrirá una nueva época en la conflictiva construcción de un "nuevo orden social" o volverá a rearticularse un neoliberalismo con rostro humano es algo que aún pertenece al dominio de las interrogaciones. En medio de la pandemia por Covid-19 la crisis del gobier-

\footnotetext{
Pontificia Universidad Católica de Chile oac2020@uc.cl

2 Por izquierda tradicional o izquierda de postdictadura entiendo fundamentalmente los partidos que se agruparon en la coalición de la Concertación de Partidos por el No desde 1988 (Partido Demócrata Cristiano, Partido Por la Democracia, Partido Socialista, Partido Radical de Chile y MAPU Obrero Campesino, entre otros) y Nueva Mayoría en 2013 (incluye, además de los partidos anteriores, al Partido Comunista de Chile y el Movimiento Amplio Social, entre otros).
} 
no de Sebastián Piñera ha logrado estabilizarse mediante el exitoso plebiscito del 2020 en el que el apruebo logró casi el $80 \%$ de los votos y mediante el éxito del proceso de vacunación que persigue estabilizar el comercio y la vida de los chilenos. La astucia del gobierno y de una clase política que fue fuertemente desestabilizada por la revuelta ha recuperado las esperanzas de estabilizar un modelo que parece descompuesto. La posibilidad de una recomposición del neoliberalismo 2.0 o con rostro humano es sin duda una posibilidad real. La recomposición depende en gran parte de los pactos de la izquierda tradicional que se halla lejos de las demandas y el descontento de la sociedad civil y cerca de la recomposición de la hegemonía neoliberal.

La recomposición es un escenario posible. Sin embargo, el descontento social es profundo y estructural y podría tomar lugar una revuelta mucho más intensa que la del 18-O. Los consensos no tienen apoyo social y ocurren en el interior de un frágil y debilitado sistema de partidos políticos. La situación no parece tener una resolución en el marco de la constitución neoliberal de 1980 y la "nueva constitución" por venir tampoco parece ser la salida. El neoliberalismo en Chile no es solo un modelo económico y constitucional de modernización, es, sobre todo, un mundo de vida que tomó lugar a partir de uno de los más exitosos golpes militares en América Latina. En este contexto de fragilidad institucional y de la pequeña apertura a un umbral de otra sociedad que ha desatado la revuelta por dignidad del 18-O, la figura moderna de Allende aparece de manera tenue en la escena política chilena. El retorno de las ideas sociales y políticas que se condensaron en el éxito del triunfo electoral de la Unidad Popular (UP) junto a la consolidación del liderazgo de Allende parece hablarnos de un tiempo recobrado. Se trata del tiempo histórico que originó la modernidad latinoamericana y que si bien parece haber sufrido una transmutación debido a los avatares del capitalismo tardío hay restos y fantasmas que habitan la temporalidad del agotamiento de los proyectos modernos.

La memoria del triunfo excepcional del médico y militante socialista Salvador Allende Gossens es uno de esos topoi de las ruinas trágicas que la modernidad arrojó como una experiencia política excepcional. En Dialéctica de una derrota (1977), Carlos Altamirano, secretario general del Partido Socialista y uno de los adversarios teóricos de Allende, pone en perspectiva la condición moderna del programa de la UP:

En el plano político y social, la Unidad Popular emerge como la continuación del antiguo Frente de Acción Popular (FRAP) creado en 1956. La incorporación de otras vertientes del pensamiento democrático otorga a la unidad de los trabajadores una nueva dimensión y la amplitud necesaria para encarar, más allá de una etapa transicional, la construcción del socialismo ${ }^{3}$.

El libro de Altamirano es una especie de oda a la tragedia y al mismo tiempo una profunda reflexión históri-

C. Altamirano, Dialéctica de una derrota, México, Siglo XXI, 1977, p. 32 . ca de la derrota de la UP. La derrota ha sido la marca de la última experiencia electoral exitosa de un programa nacional y popular revolucionario moderno. El paradigma de la derrota permea toda la interpretación de este hito político de la modernidad latinoamericana. A diferencia de lo que ocurrió en la Argentina con el fenómeno histórico de las mitológicas criaturas de Perón y Evita, en Chile la experiencia popular ha sido un mito político neutralizado o incluso castrado en su capacidad de inseminar programas y potencias trasformadoras dentro del ámbito de la izquierda tradicional. Allende es una especie de outlaw, de paria de las instituciones democráticas de la postdictadura. Su legado tiene más la forma del poema que ha quedado fuera de la composición del Estado que de una política de resistencia a la dominación de las oligarquías transnacionalizadas. La explicación del porqué el prócer del socialismo chileno y la más importante de las experiencias populares que ocurrió bajo su gobierno no ha llegado a constituir una herencia para la República de Chile debe buscarse en la crisis de identidad de la izquierda. El debilitamiento de los relatos de la modernidad política y la retirada de la gramática de la revolución social es una de las consecuencias directas del nihilismo de la izquierda de postdictadura. Esta debió negociar la llamada transición a la democracia en un contexto de crisis y agotamiento del discurso de la modernidad. En este contexto, el allendismo nunca tomó lugar en el sistema de dominación política. Por el contrario, se mantuvo fuera de las transacciones de los propios partidos de la coalición de izquierda que inauguró el triunfo del NO en el plebiscito de 1989. La figura política de Allende es demasiado problemática para los pactos de la transición democrática. La vida de la izquierda tradicional de postdictadura no habría podido emular la célebre frase peronista de William Cooke ${ }^{4}$. No es imaginable a la izquierda trasnacional de postdictadura diciendo que el "allendismo es el hecho maldito de la política del país burgués"5. Allende no constituyó la sustancia de la vida ética de la izquierda cincelada y vaciada del entusiasmo del imaginario moderno de trasformación. Los crueles años de la dictadura de Pinochet no solo redujeron a los partidos políticos de la UP a huellas cadavéricas, sino que, además, se auto-vaciaron de la potencia que estos tenían para orientarse en política. El esplendor del momento Allendista fue neutralizado de manera eficiente por lo que puede ser pensado como el fin de la modernidad plebeya.

\section{Entre excepcionalidad y dietética (empanadas y vino tinto)}

En Conversaciones con Allende: ¿logrará Chile implantar el socialismo? (1971) Régis Debray revela su fascinación por este ejemplar militante socialista. Allen-

\footnotetext{
Cf. W. Cooke, "Peronismo y revolución", en F. Martínez Heredia (ed.), La crítica en tiempo de Revolución. Antología de textos de Pensamiento Crítico, Santiago de Cuba, Editorial Oriente, 2010.

5 La frase célebre pertenece a quien fuera uno de los más importantes intelectuales peronistas. No tiene ninguna resonancia en un país como Chile donde la insularidad de la cultura intelectual impide conocer más afondo los procesos políticos en la región.
} 
de hablaba con la confianza de un estadista socialista y republicano del lado de la historia de una victoria; la victoria de la UP. El filósofo francés, quien había escrito un libro sobre la lucha armada y política en América Latina y que escribiría un importante libro sobre el Che (La guérilla du Che, 1974) está fascinado con el líder chileno y su vía pacífica al socialismo. El proceso político de la UP es inmediatamente un proceso de empoderamiento social que emulando por medios constitucionales el imaginario de la Revolución Cubana consigue el asalto al poder por la vía electoral. La posibilidad del tránsito hacia el socialismo sin derramar una gota de sangre constituyó una excepcionalidad a la idea de los focos guerrilleros, fracasados en 1967 con la derrota y asesinato de Ernesto Che Guevara en Bolivia. El análisis de Debray consideraba el éxito y los desafíos que el gobierno popular debía enfrentar desde la sensatez de que el triunfo electoral podía resultar incompatible con la vieja estructura de la modernidad parlamentaria. En la conversación el filósofo sitúa el carácter excepcional del triunfo electoral de Allende en el interior de un proceso histórico de largo aliento y expone la idea de que la experiencia chilena al socialismo está inscrita en la precocidad histórica del movimiento social:

Cualquier historiador de América Latina sabe que es en este laboratorio de experimentación social que han aparecido, anticipándose a la evolución del Continente, la primera mutual obrera (1847); el primer ferrocarril (1851); la legislación más adelantada de su tiempo (Andrés Bello 1884); la primera ley de sufragio universal que haya entrado en vigor (1884); la primera legislación social efectivamente aplicada (ley de reposo dominical, 1907, (...); la primera República Socialista de América (1932), bautizada así después por el decreto ley, después del golpe de estado de Marmaduke Grove; el primero, sino el único gobierno del Frente Popular del Continente (1938), etcétera... Sería difícil encontrar en otro país de esta parte del mundo una burguesía más precozmente constituida, segura de ella misma y expansionista, así como hallar un movimiento obrero tan sólidamente instalado, desde comienzos de siglo, en sus posiciones de clase $^{6}$.

En esta genealogía la izquierda revolucionaria encuentra la posibilidad de inventar el léxico y, así, el lenguaje de que lo que estaba ocurriendo en Chile era del orden de un acontecimiento. Este acontecimiento no está en aquel momento relacionado con el culto a la personalidad de Allende. Ese culto vendrá con su muerte o con la conversión de su figura en estética y monumento de la derrota política. La genealogía que propone Debray a Allende es de absoluta simpatía del líder. En el momento en que ocurre la conversación éste llevaba tan solo un año de presidente de la república y el entusiasmo por la revolución "con empanada y vino tinto" ocurría en una especie de carnaval. A diferencia de otras experiencias y fundamentalmente a diferencia de la Revolución Cubana (1959), nunca llegó a militarizarse. El poder plebeyo estaba lejos de pasar a ser un ejército popular. Lo que predominaba era la experiencia de subjetividad

R. Debray, Conversaciones con Allende: ¿logrará Chile implantar el socialismo?, México, Siglo XXI, 1971, p. 15. carnavalesca a lo Bajtín, es decir, el empoderamiento como festejo y espectáculo con escenografías plebeyas o plebeyizadas por el mundo popular. La escenografía se vivió como un desborde de las normas heredadas de la burguesía y de las clases oligárquicas, las cuales son puestas entre paréntesis. Un verdadero golpe plebeyo a la representación dominante de las élites blancas y acomodadas incomodó los cuerpos de clases medias y altas, acostumbradas a la "blanquitud" del poder y la riqueza. A través de la proliferación y efervescencia de una especie de micropolítica festiva que tenía el apoyo en un Estado que pretendía plebeyizarse, floreció el arte de las caravanas acompañadas de bandas musicales, murgas poblacionales y por supuesto, los sindicatos obreros y agrupaciones de campesinos. El espectáculo teatral de las manifestaciones de apoyo popular al gobierno conformó un ambiente de fiesta nacional-popular. Sin que el gobierno fuese un gobierno populista, la nacionalización del cobre y el imaginario en acto de la intensificación de la Reforma Agraria ${ }^{7}$ fueron apoyados por organizaciones de sindicatos obreros, organizaciones campesinas y mapuches e indiscutiblemente por el canto protesta (Víctor Jara, Isabel y Ángel Parra, Quilapayún, Los Jaivas, Inti-Illimani, etcétera) de una época donde el mundo de vida se abría a las clases populares. La fiesta fue vehiculizada por la fuerza social y discursiva que condensaba la consigna del gobierno del "pueblo y para el pueblo" como un elemento de distorsión o anomalía en la tradición liberal-parlamentaria.

El análisis de Debray no habla exactamente de esta anomalía, pero deja notar que en la historia de Chile la precocidad y excepcionalidad de la vía electoralparlamentaria al socialismo, está lejos de la toma del poder del Estado por la vía del carnaval. En la conversación con Allende, el histórico filósofo francés, comprometido con la revolución latinoamericana, ve que el horizonte de la pregunta por la lucha armada y por el paso militar de autodefensa y de contención de los derechos conquistados por las clases sociales más desposeídas es totalmente ajeno a la política del desborde plebeyo de las instituciones liberales. Este es el tema que siempre preocupó a autores como Tomás Moulian y Joan Garcés. Este último, asesor de Allende y una de las cabezas más lúcidas del análisis de la experiencia de la UP escribió tempranamente un libro titulado Allende y la experiencia chilena. Las armas de la política (1976). En el libro del cientista político catalán se halla una explicación temprana del colapso de la tradición leninista basada en la hipótesis de la guerra insurreccional de los obreros para la toma del

\footnotetext{
La Reforma Agraria había comenzado antes de la UP con la primera ley de redistribución de tierras que promulgó Jorge Alessandri en 1962. Entre 1970 y 1973 la efervescencia de los sectores campesinos y la política popular del gobierno permitió la expropiación de tierras a propietarios latifundistas. La consigna de Allende en el discurso sobre la propiedad agraria el 23 de agosto de 1971 señalaba: "el próximo año no quedará ni un solo latifundio en Chile". La política de la UP permitió un enorme acercamiento a la población Mapuche. Esta relación de proximidad entre Allende y los campesinos mapuches fue filmada por el cineasta Raúl Ruiz en un documental titulado Ahora te vamos a llamar hermano (1971). En cualquier caso, el lector interesado en el análisis de la Reforma Agraria puede consultar el libro de José Bengoa Reforma Agraria y revolución campesina: seguido de un homenaje a los campesinos desaparecidos (2016).
} 
Estado. Las virtudes de sus análisis consisten en ofrecer una lectura en el que la tragedia de la Unidad Popular no escamotea la pregunta por la relación entre la política parlamentaria de Allende y la guerra civil ${ }^{8}$. La interpretación de Garcés, como se sabe cercano al presidente durante todo lo que duró el gobierno popular en Chile, presenta el desenlace de la tragedia política, desde una perspectiva en la que no es posible escindir el contexto del triunfo popular de la correlación de fuerzas internacionales que se le opusieron. En otras palabras, la oposición al programa socialista de la UP no solo viene de la oligarquía nacional liberal y de los partidos políticos de centro y derecha, sino también del conjunto de países capitalistas a los que el experimento "ultra-democrático" de Allende les producía incluso más sospecha que las que causaba la idea de la revolución armada cuyo antecedente era la Revolución Cubana.

En Allende y en el modo en que concibió la experiencia de un gobierno popular la tesis insurreccional de la clase obrera no es solo opuesta a la festividad de la experiencia popular, sino que no tenía ninguna cabida en el modo de imaginar la utopía socialista. El socialismo es concebido al modo de una bacanal plebeya donde las empanas y el vino tinto tienen una función anti-insurreccional. Donde hay comida y alcohol hay fiesta y no militarización. Por eso, se puede decir que la dietética de Allende estaba inscrita en la pasión por la vida republicana de una utopía social que podía rechazar o, mejor aún, sustraerse de la militarización de la política. Era la pasión colectiva de un mundo de vida que políticamente se alejó demasiado de los enfoques (marxistas) de la toma insurreccional del poder concentrado en el Estado. Allende respetaba la tradición republicana y defendió hasta el último día de su vida las leyes de la modernidad liberal y burguesa. La guerra insurreccional al estilo de lo propuesto por lecturas basadas en los libros del general vietnamita Vo Nguyen Giap o en posiciones militaristas como las del Che Guevara o Fidel Castro era algo que no definía la política de acceso al poder y construcción de una república socialista por parte de Allende. Por el contrario, la militarización de la política, el modelo foquista de la guerra de guerrillas y/o la insurrección obrera como estrategia de asalto del poder del Estado no era parte de la dietética del socialismo chileno.

La vía electoral al socialismo estaba tramada en el horizonte de una anomalía respecto del patrón de las regularidades con las cuales debía gestarse el devenir de los procesos revolucionarios. Lo que Debray llama

El libro de Garcés, quizás uno de los mejores análisis escrito por alguien tan próximo a Allende, hoy permite pensar el concepto de $s t a-$ sis de manera muy similar a como lo hace Tatjana Gajic para el caso español en Paradoxes of Stasis. Literature, Politics, and Thought in Francoist Spain (2019). Referido al ámbito de la guerra civil la stasis es una paradoja porque permite politizar una situación política al mismo tiempo que despolitizarla. En Chile, previo al golpe militar el fantasma de la guerra civil tiene precisamente una función paradójica, es decir, permitía politizar la relación con los militares mediante el miedo a la inminencia de la guerra civil y, al mismo tiempo, despolitizaba la política de alianzas de la UP debido a que la "ultra-izquierda" deseaba la vía militar al poder. El libro de Joan Garcés muestra, precisamente, esta paradoja de la stasis. la "evolución del Continente" no era sino el imaginario de una izquierda política y teórica que suponía que había leyes morfológicas de la historia, según las cuales el socialismo era un proceso inevitable al que las sociedades avanzaban. La vía chilena al socialismo fue la apertura a la novedad de una posibilidad otra que la de la vía armada. La UP era la negación del foco guerrillero espectralizado por el triunfo de la Revolución Cubana y las consiguientes teorías hinchadas por los ánimos militarizados de la época. Estos ánimos terminaron con la captura y asesinato del "Che". La revolución a la chilena emergió, sin duda, como una posibilidad inédita e irrevocable para asegurar lo que las leyes del marxismo habían codificado como la ley nomotética de la transición al socialismo. En la morfología histórica - propuesta fundamentalmente por el archivo de un marxismo canonizado por los manuales soviéticos de la Editorial Progreso9 - el imaginario de los años sesenta enfatizaba la lucha armada y la violencia revolucionaria como únicos ejes de la toma del poder del Estado. Un sector de los intelectuales de la izquierda latinoamericana, quienes eran partidarios de las teorías del foco guerrillero, excluía la posibilidad de la vía electoral como articulación del tránsito al socialismo. En esta estela de pensamiento moderno que apoyaba el imaginario de la lucha armada, es conocida la posición que tenía el prestigioso economista y teórico egresado de la Universidad de Chicago André Gunder Frank respecto de la vía electoral al socialismo basada en una imposible política de alianza con la "lumpenburguesía"10.

En un registro similar se halla la referencia de Manuel Cabieses Donoso al movimiento de Black Power de los años sesenta. En un interesante artículo titulado "Chile: el voto o el fusil" (1969) para la revista Punto Final $^{11}$ Cabieses se refiere al discurso de Malcom X pronunciado en Cleveland el 3 de abril de 1964: "Y bien, suponiendo que ustedes no me volvieran a ver más, que yo tuviera que morir mañana, mis últimas palabras serían: el voto o el fusil"'12. El uso de uno de los líderes más importantes del movimiento de derechos civiles en

La Editorial Progreso hizo posible un conjunto de lecturas basadas en las traducciones que proveía la URSS. La máquina de traducción del imperio socialista posibilitó que la ortodoxia de los partidos comunistas de la región produjera efectos de distanciamiento de las realidades específicas de América Latina. La lectura ortodoxa se caracterizó fundamentalmente por privilegiar un paradigma evolutivo y/o teleológico. El célebre libro de Ernesto Laclau \& Chantal Mouffe Hegemonía y estrategia socialista. Hacia una radicalización de la democracia (1985) es ejemplar en la crítica al marxismo evolucionista y etapista. También lo es el extraordinario libro Análisis del pasado y proyecto social (1982) escrito por el historiador español Josep Fontana.

10 André Gunder Frank fue un extraordinario teórico que polemizó con la teoría de la CEPAL (Comisión Económica para América Latina y el Caribe) y elaboró una seminal compresión de los fenómenos políticos a partir de la hipótesis de la subordinación neocolonial de los países latinoamericanos al sistema-mundo. Residió en Chile desde 1969 y vivió todo el proceso de auge y caída de la UP.

11 La revista Punto Final vinculada al Movimiento de Izquierda Revolucionaria (MIR) era una de las más críticas a la UP y, al mismo tiempo, una de las más interesantes en términos de su producción intelectual y de la convocatoria a intelectuales de distintos sectores de la izquierda.

12 La traducción completa de este discurso se encuentra en revista Punto Final 35, 1969. 
los Estados Unidos para tensionar la polémica entre la lucha electoral y la armada estaba basado en el siguiente diagnóstico:

Pero, todo esto ¿qué tiene que ver con Chile?, se preguntarán aquellos que conciben nuestra realidad ajena a la del continente. Tiene que ver, lógicamente, en cuanto las técnicas de retención y usufructo del poder que utilizan las burguesías y el imperialismo alcanzan también a nuestro país. La debilidad -en este sentido- del sistema democrático burgués como fórmula de gobierno en América Latina, ha ido minando las bases de sustentación de ese régimen en Chile. El sistema ha caído en el descrédito y con él las instituciones que le afianzan ${ }^{13}$.

Escrito un año antes del triunfo electoral, el tono de este artículo de Cabieses, su comparación con el clamor por la violencia armada en el movimiento del Poder Negro de los EE. UU., un galopante guevarismo y una cierta pasión por el imaginario armado de la revolución atravesará los debates que polarizaron la estructura partidaria de la UP hasta el momento de su derrota. Se puede sin duda considerar que el paradigma de la lucha armada no solo será contenido por la UP, sino también denunciado como una posición política que caía en la propia consigna leninista desarrollada en el famoso texto "El comunismo de izquierda, una enfermedad infantil", que Lenin escribió en 1920 para criticar el desviacionismo de la "ultraizquierda" europea. La crítica de Lenin se acomodaba muy bien a los militantes del Movimiento de Izquierda Revolucionaria (MIR), quienes siempre mantuvieron las tensiones entre el imaginario armado y la dietética del socialismo con empanas y vino tinto.

De hecho, en 1975 el Partido Comunista de Chile respondiendo a una carta del MIR “repite" la crítica de Lenin acusando a la extrema izquierda que se oponía a los "partidos tradicionales" de la UP de "ultrismo pequeñoburgués". Los comunistas chilenos, incluso después del golpe, señalaron su oposición a la violencia armada y reconocieron que la "ultraizquierda" había acertado en intentar "ganar la conciencia" de las fuerzas armadas para el proceso revolucionario. La carta es una especie de epístola apasionada por un leninismo "oportuno", "diverso" y doctrinal que funcionaba tanto para defender el constitucionalismo del paradigma liberal-republicano en el que se inscribió la dietética de la vía pacífica como el imaginario de la toma del poder por la vía armada ${ }^{14}$. Lo cierto es que estas dos opciones son las dos caras de una misma modernidad política, cuyo destino fue su extenuación o debilitamiento sistemático por el giro de una política que fue vaciada de su "potencia plebeya". Pero también por lo que de manera temprana sospechó André Gunder Frank en sus análisis de la teoría de la dependencia, enfatizando que ésta no debía entenderse como "meramente externa", "impuesta a todos los latinoamericanos desde afuera y contra su voluntad, sino que la dependencia es igualmente una condición «inter-

13 M. Cabieses Donoso, "Chile: el voto y el fusil", Punto Final 73, 1969, p. 2.

14 La carta circuló de manera clandestina. Hoy se puede encontrar escaneada en Internet: https://es.scribd.com/document/355874745/PCultraizquierdismo-caballo-de-Troya-del-imperialismo-pdf (revisada el 24 de abril, 2021). na» e integral de la sociedad latinoamericana"15. Por lo tanto, los conflictos con la "lumpenburguesía" no solo eran inevitables, sino que, además, la "dependencia integral" hacía inviable una transformación radical desde la interioridad de las instituciones heredadas de la modernidad burguesa. Los análisis de Gunder Frank sostenían críticas bastante duras a las teorías de la Comisión Económica para América Latina y el Caribe (CEPAL) y conducían a una sospecha radical respecto de la viabilidad de proyectos de emancipación popular y nacionaldesarrollista ${ }^{16}$.

Esta sospecha se basaba en el papel subsidiario de la burguesía con respecto a la dependencia del capitalismo metropolitano. En su análisis de la dependencia integral Gunder Frank no afirma abiertamente que los proyectos nacional populares constituyan un error desde el punto de vista de la dependencia integral, pero sí que la burguesía nacional y las alianzas con este sector, por su subordinación al capitalismo metropolitano, no podían resolver su atadura desde la institucionalidad heredada de los poderes externo e internos a las sociedades latinoamericanas. Esta hacía de la vía parlamentaria una especie de imposible estructural. Gabriel Salazar, en una interesante entrevista sobre su militancia en el MIR, señala que se hizo militante porque escuchó y entendió la hipótesis de Gunder Frank, la cual el historiador social resume de la siguiente manera: "la vía parlamentaria al socialismo o al desarrollo estaba entrampada porque se había intentado muchas veces y esa vía estaba cerrada; en consecuencia había que buscar otra vía y esa vía nos llevaba derechito (...) a plantear la lucha armada o una vía de acción directa como lo planteaba Clotario Blest" ${ }^{17}$. En cualquier caso, la crítica a la ineficacia de la militarización de la política y la crítica a la hipostasiada excepcionalidad de la historia institucional de Chile siguen hasta el día de hoy resonando como el verosímil de que ninguna de las dos opciones logró oponerse a la actual sociedad neoliberal.

\section{Desmitificación y olvido}

En Chile actual. Anatomía de un mito (1997) Moulian critica de manera fuerte la hipótesis del paradigma histórico-democrático. La excepcionalidad de la vía par-

15 A. Gunder Frank, Lumpenburguesía: Lumpendesarrollo. Dependencia, clase y politica en Latinoamérica, Buenos Aires, Ediciones Periferia S.R.L., 1973, p. 13.

16 La CEPAL estuvo dirigida por el economista argentino Raúl Prébish y tenía sede en Santiago de Chile. Tuvo una clara inspiración en el imaginario keynesiano y en términos económicos promovió el papel de los estados en el desarrollo productivo de la región basado en la idea de la industrialización por sustitución de importaciones. El eje del pensamiento económico de la CEPAL, podríamos decir, está basado en una especie de keynesianismo criollo a favor de políticas desarrollistas y de una reforma agraria en la región. Los golpes militares en el Cono Sur y el giro radical a un liberalismo extremo pondrán fin en la década de los ochenta al imaginario nacional-desarrollista. El fin de este imaginario es el fin del keynesianismo del "tercer mundo" latinoamericano.

17 La entrevista se puede consultar en el siguiente enlace: https://www. londres38.cl/1934/w3-article-100670.html. La referencia a Clotario Blest es importante, pues se trata de uno de los fundares del MIR, pero también es una figura emblemática del Movimiento Obrero en Chile. 
lamentaria al socialismo la interpreta en el interior de una lógica del olvido:

En realidad, esa ejemplaridad estaba construida sobre esa mezcla del olvido y de la mistificación. Olvido de los comienzos de furia, de la ineficacia de los tiempos de prebendas, desorden e inestabilidad que se vivieron entre 1891 y 1932. Olvido de las leyes de proscripción de los comunistas entre 1948 y 1958, del campo de concentración de Pisagua. Mistificación sobre la profundidad de la democracia chilena $^{18}$

A pesar de la mistificación de la democracia y tal como ocurre en el lenguaje soberano del ajedrez, el gobierno de la UP fue un jaque excepcional a las clases oligarcas y a los partidos políticos de centro como la Democracia Cristiana y los partidos de la derecha más extrema que se agrupaban en el Partido Nacional (PT). De acuerdo con Moulian el jaque mate que debía dar muerte al rey en un tablero de tácticas y estrategias populares nunca se produjo porque la excepcionalidad olvidaba - por Allende y Debray, entre otros- a lo largo de la historia de Chile ha sido implacable en golpear insurgencias plebeyas (o no) contra la estructura parlamentaria que sostiene y protege el orden oligárquico desde el siglo diecinueve. Todas las rebeliones, carnavalescas o militarizadas, a favor de la justicia social fueron derrumbadas a punta de metralla, genocidios y campos de concentración $^{19}$. La mistificación de la vía parlamentaria al socialismo, si bien operó como elocuente retórica de un populismo inédito en la historia política, no logró consolidar su programa social. La experiencia chilena de un poder plebeyo conmovió a los intelectuales de todo el globo terráqueo. Pero, lo que más conmovió no fue su éxito en las urnas ni, menos aún, la expresividad de lo plebeyo ejerciendo un poder popular que amenazó a la oligarquía e intimidó a las clases sociales acomodadas, sino su tragedia política y social. Es posible pensar que esta conmoción se deba a la intuición de que se trata de la última tragedia de la modernidad política en América Latina, pero también al predominio del paradigma de la comprensión trágica de la política ${ }^{20}$. La derrota trágica del gobierno popular es la derrota del proyecto nacionaldesarrollista de la izquierda moderna y, en consecuencia, el triunfo de un liberalismo extremo cuya genealogía se remonta al librecambismo del Estado-portaliano como genealogía de la fortificación militar de la propiedad privada.

En efecto, la desmitificación de la experiencia plebeya que afirmó la positividad de su existencia política en la fiesta y lo carnavalesco, requiere de la desmitificación

18 T. Moulian, Chile actual. Anatomía de un mito, Santiago de Chile, LOM Ediciones, 1997, p. 151.

19 Uno de los libros más importantes sobre las Fuerzas Armadas en Chile fue publicado por Gabriel Salazar. El libro titulado Ejército de Chile y la soberanía popular narra la historia del ejército libertador de O’Higgins, el cual tenía una base plebeya que luego sería privatizada y terminaría derrocando al presidente Balmaceda en 1891 definiendo su historia golpista. El libro es uno de los más serios intentos por desmitologizar la historia del ejército de Chile desde la perspectiva del "bajo pueblo" ciudadano.

20 Eduardo Rinesi dedicó un libro importante sobre este paradigma. El lector interesado puede consultar: Política y tragedia. Hamlet, entre Hobbes y Maquiavelo (2003). de la excepcionalidad. ¿Qué fue lo exactamente excepcional? Lo excepcional de la UP es sin duda la modernidad política de la participación plebeya en el proyecto nacional-desarrollista y el carisma de Allende. Excepcional fue el hecho de que un militante socialista que defendió, como último de los grandes estadistas de la tradición liberal parlamentaria, la democracia y la constitución. Nadie como Allende ha encarnado de manera tan radical los valores constitucionales de la república liberal-democrática. Sin duda, era socialista y representaba el impulso nacional-desarrollista de la izquierda, pero sobre todo era respetuoso de las leyes y de las formas institucionales de la república. Su convicción en la democracia se resume en las palabras que marcaron la derrota: "pagaré con mi vida la lealtad del pueblo". Sin embargo, esta convicción hubiese sido insignificante sin el cortocircuito que provocó el desborde de lo plebeyo con la estructura parlamentaria de la democracia burguesa. La democracia como expresión material de las clases subalternas -o como "democracia salvaje" para usar la expresión teórica de Abensour ${ }^{21}$ - constituyó una amenaza real a las tradicionales convenciones del parlamentarismo liberal. Por eso, no se puede confundir la mistificación del líder sacrificial y la objetividad experiencial del desborde plebeyo que de facto llegó a constituir lo impresentable en el interior de instituciones que estaban destinadas a las élites, a las clases acomodadas y a la oligarquía criolla.

En el libro de Philippe Sollers, Sobre el Materialismo: del atomismo a la dialéctica revolucionaria (1974), aunque en un registro un poco distinto del de Moulian, aparece la misma actitud des-mistificadora y de denuncia del fetiche político de la tradición liberalparlamentaria. Sollers, tan solo a un año del golpe de 1973, repasa una genealogía teórico-conceptual de la historia de la filosofía para defender el materialismo. No es menester aquí revisar los argumentos filosóficos de Sollers -que en todo caso, versan sobre su posición respecto del maoísmo- sino mostrar cómo la experiencia plebeya de la UP funcionó como una especie de ejemplo paradigmático. Lo que Sollers ve es el modelo de saber en el que estaba fundado el fetiche político de la vía electoral. La vía chilena que se impone modernamente siguiendo programas teleológicos estaba destinada al fracaso. La imposibilidad de avanzar hacia un proyecto nacional socialista que solo se sostenía en el desborde y el entusiasmo de las clases subalternas y en el supuesto de las leyes heredadas de la oligarquía chilena dueña del capital y del ejército, no podía terminar bien. Sollers escribió lo siguiente sobre el límite de la experiencia política de la UP:

Chile constituye un ejemplo particularmente notable. He aquí un país que, colmando las fantasías evolucionistas, parecía acceder al socialismo de manera natural, legalmente, es decir, sin revolución. Se trataba, en definitiva, del primer caso en la historia, ya que el paso al socialismo o cualquier otra transformación de las rela-

\footnotetext{
21 M. Abensour, "Democracia salvaje y principio de anarquía", La democracia contra el Estado. Marx y el momento maquiaveliano, Madrid, Los libros de la Catarata, 2017, pp. 205-288.
} 
ciones de producción se desarrolla siempre a favor de la guerra o de un ejército extranjero. Este último punto es decisivo, pues formándose una idea "pacífica" de la evolución de la humanidad, Chile parecía responder a esa expectativa. Pero qué es lo que pasa: push fascista que contraría la creencia humanista-evolucionista. Catástrofe para la izquierda occidental. Insisto en que el marxismo no ha pensado el fascismo en profundidad por una ignorancia tradicional del peso material de la ideología ${ }^{22}$.

La hipótesis que en 1974 desarrolla Sollers estaba destinada a probar que el marxismo había sido incapaz de explicar el fascismo por falta de apropiación del psicoanálisis. Así, cree que solo Wilhelm Reich -a través del descubrimiento de Freud- había vislumbrado en el anclaje del movimiento obrero la importancia de la libido como categoría de análisis de lo político. La crítica de Sollers a la derrota de la UP funciona como crítica a las concepciones evolucionistas de la historia que abundaban tanto en el marxismo como en la cabeza de los líderes socialistas. Lo que Sollers no ve y quizá no puede verlo es que la UP es el desborde de la libido en el interior o en la inmanencia de la democracia parlamentaria. El golpe de estado que en 1973 liquidó la dietética política de la "empanada y vino tinto" no tuvo en lo más mínimo ribetes del fascismo histórico. El fascismo europeo fue un movimiento de masas que no puede ser comparado con lo que aconteció con el fin catastrófico del desborde libidinal de la UP. La energía libidinal con la cual las masas fascistizadas invistieron a líderes como Hitler y Mussolini e incluso con la cual expresaron las masas soviéticas el epopéyico "culto a la personalidad" de Stalin, declarándole amor incondicional, no tiene ningún parentesco con la dictadura que Pinochet y la junta militar impusieron en Chile. La dictadura que destronó la tradición liberal parlamentaria y decidió durante más de 17 años sobre el derecho de vida y muerte no se apoyó en un movimiento de masas, sino en el principio de crueldad. La crueldad como principio de articulación se ha compuesto del terrorismo de la dictadura de 1973, de la Constitución de 1980 y de los 30 años de pacto democrático de la coalición de partidos de izquierda y de centro agrupados en La Concertación y Nueva Mayoría con el orden neoliberal. La revuelta del 18-O del 2019 interrumpió esta articulación desatando un escenario en que el legado moderno de la UP se halla ausente de las coaliciones de partidos de la izquierda tradicional. ¿Por qué el mito de Allende sigue siendo un legado que toma la forma de la aparición de un fantasma que no puede ser exorcizado? La respuesta a esta pregunta hay que buscarla en el suicidio de Allende y en los arcanos de la democracia de estos últimos treinta años ${ }^{23}$.

22 P. Sollers, Sobre el Materialismo: del atomismo a la dialéctica revolucionaria, Valencia, Pre-Textos, 1979 [1974], p. 169.

23 El paradigma neoliberal o más precisamente hablando de liberalismo extremo, es lo que podríamos llamar la condición rizomática y micropolítica del fascismo a la chilena. Lo que adviene después del golpe de 1973 es un "fascismo molecular" y muchas veces imperceptible o encubierto en el pelaje de la razón cínica del neoliberalismo parlamentario. Este cinismo ha irrigado todo el tejido capilar de las instituciones sociales y hoy -sumado al agotamiento moderno del carisma- hace imposible un retorno de la experiencia excepcional y plebeya de la UP.

\section{Neutralización de la experiencia plebeya}

En su célebre libro La democracia contra el Estado Miguel Abensour define el concepto de lo arcano como el secreto mejor guardado de un determinado orden político. Con esta definición, cuyo objeto es problematizar la democracia moderna y su relación con las instituciones, Abensour habilita la siguiente pregunta: ¿Cuál es el arcano del modelo de liberalismo extremo y de la democracia estatal en Chile? La respuesta histórica a esta pregunta ha sido respondida por distintas disciplinas de las ciencias sociales, la ciencia política, la filosofía, la historiografía y la Crítica Cultural ${ }^{24}$. Estas disciplinas convergen en el espacio argumental de que la democracia estatal o estatizada es un efecto de la derrota del imaginario revolucionario y del socialismo republicano que tomó lugar entre 1970 y $1973^{25}$. En este sentido, la experiencia de la UP es el último eslabón de la cadena histórica en el que se condensó la modernidad criolla y sus posibilidades emancipatorias para las clases desposeídas desde la estructura jurídico parlamentaria que emergió con el nacimiento de las repúblicas postcoloniales del siglo $\mathrm{XIX}^{26}$. La derrota de la UP ha sido narrativizada como la historia política de un fracaso ejemplar, una especie de tragedia griega: el intento de la izquierda de construir el socialismo por la vía pacífica (electoral) y su caída en la más profunda de las derrotas. Ha predominado una interpretación melancólica, el dominio de la hermenéutica de la tragedia política que cierra la política emancipadora liberal republicana, desde Patricio Marchant al historiador italiano Enzo Traverso. La codificación en una historia impotente de la lágrima y de la memoria han funcionado como contenciones estatalizadas a los desbordes plebeyos ${ }^{27}$.

24 Los análisis más interesantes respecto del arcano de la democracia neoliberal siguen siendo aquellos que posibilitaron las lecturas de intelectuales como Nelly Richard y Tomás Moulian. Todo lo que ha seguido con posterioridad a los libros de estos dos autores ha sido tributario de Chile Actual. Anatomía de un Mito y de al menos tres de los libros escritos por Richard: Márgenes e instituciones. Arte en Chile desde 1973 (1987), La Insubordinación de los signos: cambio político, transformaciones culturales y poéticas de la crisis (1994) y Residuos y metáforas: ensayos de crítica cultural sobre el Chile de la transición (1998).

25 Se puede hablar de un socialismo republicano porque la historia de la UP es la continuidad del programa moderno de emancipación postcolonial que surgió con los procesos de independencia. De hecho, los discursos inaugurales de Allende hablan desde el imaginario independentista de un largo siglo XIX que llegaría a su fin con el golpe de 1973.

26 El tema de la república se encuentra en los teóricos que intentan pensar el capitalismo como un sistema mundo, como fue el caso de André Gunder Frank, o en el análisis del sociólogo y ensayista peruano Aníbal Quijano, quien usa la categoría de la "colonialidad del poder".

27 El libro de Patricio Marchant que en el caso de los intelectuales chilenxs domina la escena interpretativa de la llamada postdictadura se titula Escritura y temblor (2000) y el libro de Traverso en el cual la interpretación de la izquierda se codifica en el artículo que escribió Walter Benjamin sobre la izquierda melancólica se titula Left-Wing Melancholia. Marxism, history, and memory. Desde la perspectiva de Marchant, el país que había logrado comenzar la construcción del socialismo por la vía pacífica, de golpe perdió la palabra. Desde la actualidad, esta sentencia puede también ser interpretada como la falta moderna de un estado de palabra en la esfera de la política. El golpe a la palabra sería así co-extensivo con la crisis devastadora que sufre la estructura liberal parlamentaria desde 1973 y, cuyo punto más intenso de su ruina, habría sido revelado por los distintos momentos de desobediencia civil y rebeliones del siglo veintiuno. Una 
La captura estatal y antropológica de la memoria es cifrada en la narratología de la transición a la democracia y el fin de programas emancipadores. La ruina y la catástrofe de los programas de emancipación es exorcizada o redimida por dispositivos de institucionalización cultural de los conflictos. En los museos y en instituciones de derechos humanos la historia política de una nación deviene cultura. De esta manera, figuras conflictivas, como la de Allende, son neutralizadas mediante políticas de museificación, producción de saberes historiográficos o mediante una filosofía especulativa de la derrota que se sostiene en la tematización freudiana entre lo normal y lo patológico del trauma, interpretado según categorías del "duelo y melancolía". La UP es el último clamor de los proyectos populares modernos y posiblemente el análisis en términos de duelo (transferencia del dolor y sustitución del objeto de la pérdida) o melancolía (imposibilidad de transferencia y pérdida de la realidad por no poder sustituir el objeto perdido) no logre comprender la relevancia del exceso que su experiencia produjo. Es muy probable que la melancolía de la izquierda estuviera en la condensación de las luchas anteriores al fracaso y la derrota de 1973. En otras palabras, una melancolía definida por la fidelidad al objeto (ni presente ni ausente) de la pulsión emancipadora ha recorrido todas las luchas sociales de la modernidad política. En Chile, las utopías que en el siglo XIX resonaron en los escritos de Santiago de Arcos, Francisco Bilbao, considerados los padres del socialismo chileno, logró consolidarse como imaginario actualizado en el programa de Allende y la UP. Se podría decir que bajo su conflictivo e inestable gobierno las clases trabajadoras oprimidas durante todo el siglo XIX y XX fueron redimidas a través de la expresividad de lo plebeyo. Este empoderamiento de las clases trabajadoras permite decir que en el gobierno de Allende no había ninguna posibilidad de sustituir el imaginario social de las utopías sociales de la modernidad por la transferencia de mercantilismo absoluto que originó el librecambismo de la hegemonía neoliberal que toma lugar con la dictadura ${ }^{28}$.

Entre 1970 y el 11 de septiembre de 1973, la democracia salvaje que experimentó el Estado en los mil días de unidad popular no fue una redención cultural -como la que suelen realizar los estados neoliberales en nombre de la "preservación de la memoria"- sino política. El gobierno de la UP redimió a las clases oprimidas al transformarlas en actores fundamentales de la participación

hipótesis que no podría desarrollar en este artículo es la siguiente: hay una complicidad no buscada entre el nihilismo político producido por el giro melancólico de la izquierda intelectual y el testimonio antropológico coaptado como política cultural. Así, entre la melancolía y el testimonio, se persigue una neutralización política de los fantasmas de la modernidad latinoamericana. En la escena intelectual chilena, los efectos del giro melancólico de la izquierda habrían producido una especie de hipostasis de la historia de la lágrima, cuya fuerza paralizante se debe a que entre el "golpe a la palabra" y la lágrima cosificada se articula el mercado y el turismo cultural de la memoria.

28 Los cordones industriales fueron el modo de articulación molecular de la Unidad Popular. Estaban formados por obreros y, en el interregno más intenso de los antagonismos sociales, se organizaron como un importante bastión no-militar de defensa del gobierno de Allende. El texto, entre otros, que mejor recoge esta historia es el de F. Gaudichaud, Chile 1970-1973. Mil dias que estremecieron al mundo, 2016. del poder del Estado ${ }^{29}$. Las empoderó e hizo de esa debilidad histórica de lo plebeyo que parece inherente a la irrupción política de los oprimidos, lo que Walter Benjamin había visto e interpretado como una "débil fuerza mesiánica a las que el pasado tiene derecho a exigir sus reclamos" ${ }^{\prime 30}$. La experiencia popular llegó a ser redimida de la histórica cargada de injusticias y los reclamos tuvieron la audibilidad y la complicidad del presidente. Sin embargo, la redención no tuvo ni un final feliz ni menos aún una reconciliación con la burguesía y los poderes supranacionales de aquella época de apertura y cierre de un umbral plebeyo de la modernidad. En esta estela interpretativa, el pensamiento de Tomás Moulian es una de las elucidaciones más próximas a la manera en que Benjamin pensó la temporalidad de los oprimidos. Moulian verá en el mesianismo de la experiencia popular las debilidades que el proceso político tenía en el momento de su mayor intensidad. En Conversaciones interrumpidas con Allende (1999) distingue el carácter excepcional de la experiencia de gobierno y empoderamiento popular y, al mismo tiempo, percibe la debilidad de las fuerzas plebeyas como expresión soberana del poder del Estado:

La Unidad Popular significó un momento crucial en la búsqueda de nuevas experiencias socialistas. Pero, el gobierno de Allende, que parecía la inauguración de una nueva posibilidad, terminó en el hoyo negro de la persecución y la muerte. Con el trágico derrumbe de la "vía chilena" comienza el cierre de un ciclo, que termina con el fracaso posterior del eurocomunismo. El ciclo cerrado es el de la esperanza en nuevas trayectorias y formas de realizar el socialismo. Hay que colocar la "vía chilena" en esa gran perspectiva histórica. Aún con los toscos materiales teóricos con la que ésta fue creada, representó la esperanza de que podía llegarse al socialismo sin el peso de la sangre originaria $^{31}$.

El entusiasmo plebeyo de la materia colectiva, un mesianismo configurado por la novedad excepcional de un empoderamiento plebeyo y las habilidades del líder fueron el barbecho de un mundo social articulado desde los valores modernos e ilustrados del socialismo. En estos valores irrenunciables se expresó el umbral de la modernidad plebeya. El experimento de la vía pacífica al socialismo hace posible escapar lo que de mane-

29 La experiencia de las clases trabajaras de comienzos del siglo XX se expresará en las mancomunales obreras y en el legado sindical de uno de los importantes herederos del legado de la Comuna de Paris (1871) y fundador del Partido Comunista en Chile Luis Emilio Recabarren. En los años cincuenta el intento por articular a las clases trabajadoras en un proyecto político hallará en los Frentes Populares en la experiencia de la UP. El momento más intenso de realización moderna de un poder popular expresado y articulado, aunque débilmente, desde la estructura parlamentaria de la república.

30 W. Benjamin, Tesis sobre la historia y otros fragmentos, B. Echeverría (Intro. y trad.), México, Ediciones UACM \& Editorial Itaca, 2006 , p. 37. Usamos aquí la traducción del filósofo ecuatoriano Bolívar Echeverría por elección afectiva. La traducción de Pablo Oyarzún es muy distinta y probablemente sea la más cuidada de las traducciones que existen de Benjamin. El libro de la traducción de Oyarzún donde se halla su traducción Sobre el concepto de historia se titula Walter Benjamin. Dialéctica en suspenso (1996) y fue publicado por Lom Ediciones en Santiago de Chile.

31 T. Moulian, Conversación interrumpida con Allende, Santiago de Chile, LOM Ediciones, 1998, p. 65. 
ra enfática Moulian señala como el "peso de la sangre originaria". El diseño de esta escapatoria fue el propio éxito electoral de Allende, el cual se tradujo en el mejoramiento de las condiciones de las clases subalternas, en la proliferación de programas sociales que mejoraron la vivienda social, la salud pública e implementaron la educación gratuita. Entre muchas otras proezas y a una velocidad inesperada el gobierno de Allende nacionalizó el cobre, principal recurso minero del país e inició uno de los más intensos programas de reforma agraria que debilitó a la oligarquía terrateniente. Este proyecto nacional-desarrollista estaba destinado a evitar la "sangre originaria" y, así, poder hacer de la novedad de la revolución socialista un paradigma alternativo de emanación moderna de la "potencia plebeya".

En la consagración de los más altos ideales del socialismo la sangre no sería derramada por la izquierda. La novedad de la vía pacífica al socialismo consistió en evitar lo sangriento de las luchas de clases. El desgarramiento de la sociedad civil, el asesinato y el desangramiento de los mundos de vida de una nación latinoamericana, supuestamente exitosa en la construcción de sus instituciones democráticas, no debía producirse. Evitar el origen de las nuevas leyes fundadas en la guerra fratricida estaba en la base del programa originario de la fundación de la excepcionalidad de la vía pacífica al socialismo. Por eso, Allende hasta el último momento, antes de la ofrenda altruista de su suicidio, defendió la posibilidad de escapar a la guerra civil. En esta escapatoria política, y en el interior de un experimento liberal-constitucionalista sin precedentes, puede aproximarse a la hipótesis de que Allende y la UP fueron el acontecimiento de más intensidad en la plebeyización de la política y sus instituciones modernas. Este acontecimiento sin embargo no llegó a constituir mundos de vida social. La plebeyización de la política abrió el umbral que se cerraría trágicamente sin ninguna posibilidad de retornar al punto de partida del triunfo electoral del 4 de septiembre de 1970. Su tragedia fue consumada debido a la falta casi absoluta de la militarización del proyecto popular, y la renuncia basada en la violencia de la revolución militarizada es algo a lo que nunca accederá el saber de ninguna disciplina. Al igual que la plebeyización del interregno político durante su gobierno, la fidelidad con la que Allende defendió la vía pacífica al socialismo es del orden de un acontecimiento. Esto no significa confundir la estrategia política de la vía pacífica al socialismo con el romanticismo de un umbral de mundo que puede nacer exento de violencia.

El pacifismo de Allende es moderno, liberal y profundamente constitucional, pero a su vez, se trata de un pacifismo que politizó el interregno político desde la posibilidad de una apertura a lo que en aquella época se entendía por socialismo. El relato de este pacifismo nunca dejó de ser respetuoso de las leyes constitucionales de la República, pero tampoco carecía de la violencia que el proyecto popular movilizaba contra las clases burguesas y la oligarquía. Lo dijo Allende una y otra vez y lo rememoró en su último discurso: "[S]in tener carne de mártir, no daré un paso atrás. Que lo sepan, que lo oigan, que se lo graben profundamente: dejaré la Moneda cuando cumpla el mandato que el pueblo me diera, defenderé esta revolución chilena y defenderé el Gobierno porque es el momento que el pueblo me ha entregado. No tengo otra alternativa. Sólo acribillándome a balazos podrán impedir la voluntad que es hacer cumplir el programa del pueblo"32. Esta convicción es una herencia muy profunda, arraigada en los efectos del imaginario de la soberanía como ejercicio de la voluntad democrática del pueblo. Allende se siente elegido y, sin duda, es el elegido dentro del marco de las leyes de la República. Como si se tratase de una especie de ofrenda a las tradiciones pacíficas de las leyes constitucionales, donará su cuerpo para defender la incompleta modernidad del socialismo a la chilena.

\section{La "pequeña" victoria en el interior de la derrota}

La ofrenda del suicidio de Allende tuvo efectos que posiblemente no fueron deseados por el presidente socialista. En la tipificación de los suicidios que hace Emile Durkheim el suicidio altruista se realiza por un Bien que es mayor que la vida del yo. El yo es sacrificado en una donación a la continuidad de la vida buena - la vida socialista- de un grupo social o de una nación ${ }^{33}$. Allende había dicho que no tenía pasta de apóstol ni de mártir $\mathrm{y}$, sin embargo, su suicidio es lo más cercano a las tipificaciones durkheimnianas en las que el mártir, en un acto altruista, hace donación de su vida. El suicidio del "compañero presidente" es un acto ético ${ }^{34}$. Y, como tal, no fue una acción desesperada en medio de los bombardeos, sino el paso al acto en medio del impasse de la violencia de un anunciado golpe militar. Ese día, 11 de septiembre, es el inicio de la crueldad como principio de articulación de lo que sería el liberalismo extremo que cerraba y truncaba el devenir (im)posible de la modernidad latinoamericana. En ese escenario de cierre de lo que había sido el más importante de los proyectos de poder popular, el suicidio de Allende intentó salvar la modernidad del socialismo. Los 1000 días de experiencia plebeya cargados del pacifismo que, efectivamente, detuvo la guerra civil, pero no el golpe militar, llegaba a su fin generando un hiato en la modernidad criolla. Con el paso al acto de Allende todo el peso de la sangre derramada recae en la derecha feroz y sus complicidades con la Democracia Cristiana. La derecha que había organizado grupos fascistas y había perpetrado sabotajes sistemáticos no dudó en coludirse con los peores sectores

32 S. Allende en H. Latorre Cabal, El pensamiento de Salvador Allende, México, Fondo de Cultura Económica, 1974, p. 132.

33 La estela del suicidio de Allende constituye hasta hoy un trauma para la izquierda moralista que prefiere no hablar de lo que se debería hablar, precisamente, porque el suicidio del presidente es algo, como veremos, que se halla en las antípodas de un acto melancólico. El suicidio egoísta o anómico son dos de las tipificaciones empleadas por Emil Durkheim (1897) con las que no puede pensarse el acto de auto-aniquilación de Salvador Allende.

34 La palabra "compañero" - los que comparten el pan- para un autor como Patricio Marchant llegó a constituir la experiencia acontecimental de la UP. El compañero presidente es parte de esta acontecimental. El lector interesado en este tema puede consultar el siguiente texto: "Desolación. Cuestión del nombre de Salvador Allende (1989/90)", en Escritura y temblor, pp. 213-234. 
de las Fuerzas Armadas (FFAA) y de seguir los consejos de Washington. La derecha conspiró y negoció con la administración de Richard Nixon el golpe de 1973 desplegando la crueldad como un principio ajeno a los valores del respeto a la vida y a las diferencias. Pero, sobre todo, ajeno a las instituciones y las leyes precariamente construidas por la modernidad de la república.

En Ethics of the Real. Kant, Lacan [Ética de lo real. Kant, Lacan] (2000) Alenka Zupančič argumenta que el acto ético no es idéntico a las acciones que solemos realizar cotidianamente. Por el contrario, se trata de un acto perfecto que interrumpe la normalidad de lo cotidiano. El acto ético vinculado al suicidio desborda cualquier performance destinada a la exposición artística o meramente política del cuerpo. Sus efectos no dependen de la continuidad del cuerpo, sino más bien de aquello que a través de la auto-aniquilación de este se interrumpe en la normalidad de cualquier acción.

The act differs from an "action" in that it radically transforms its bearer (agent). After an act, I am "not the same as before". In the act, the subject is annihilated and subsequently reborn (or not); the act involves a kind of temporary eclipse of the subject. The act is therefore always a "crime", a "transgression" - of the limits of the symbolic community to which I belong. It is in relation to these features of an act that Lacan claims that suicide is the paradigm of every ("successful") act. Yet we must be very careful in our understanding of this statement, because what is at stake is not simply the (voluntary) death of the subject ${ }^{35}$.

La teoría del acto como interrupción de las acciones que componen y a su vez son compuestas por el orden simbólico está en el centro de la tragedia política de la UP. Por un lado, el orden simbólico de la modernidad liberal es perforado por los aviones que bombardean La Moneda dando origen a la verdad del principio de crueldad. Este principio, con mayor rigor e intensidad, va a caracterizar al gobierno de la dictadura y su prolongación en los gobiernos neoliberales de la llamada Concertación y Nueva Mayoría. Por otro lado, se puede decir que el acto del suicidio desestabiliza la continuidad de las acciones destinadas a consumar el éxito del golpe militar como imposición ilegítima del nuevo orden (neoliberal) que vendrá. Al mismo tiempo, aunque de manera residual y fantasmática, durante todo el periodo de dictadura y transición a la democracia y/o postdictadura el acto ético de Allende permite la emanación de resistencias moleculares no localizables en las formas modernas de organización política ${ }^{36}$. En efecto, el acto ético de Allende transgrede la materialidad de la

35 A. Zupančič, Ethics of the Real. Kant, Lacan, London, Verso, 2000, p. 83 .

36 Estas formas se despliegan principalmente durante la conmemoración del 11 de septiembre y se hallan analizadas tangencialmente en el libro El puño fragmentado. Subjetividad militante de la izquierda en el Chile post-dictatorial (2008) del cientista social y político Freddy Urbano. Se trata de un libro en el que se puede encontrar la lectura de los síntomas de la crisis de los partidos políticos. El libro contiene la hipótesis de un cambio en la subjetividad militante de los partidos de izquierda y permite afirmar que respecto de las organizaciones de jóvenes pobladores el aura residual de Allende resiste en los lugares no siempre localizados por la oficialidad o la cultura de los partidos políticos de izquierda. vida y, por lo tanto, todas las leyes seculares incluyendo la prohibición cristiana del suicidio. Esta transgresión es su última batalla.

Pero ¿es este un acto de izquierdas? Pensamos que no lo es debido a que la izquierda o la derecha son posiciones ideológico-políticas y, como tales, quedan del lado de las acciones. Es imposible que no resuene en la tragedia del suicidio de Allende la célebre frase de Spinoza "uno no sabe lo que puede un cuerpo" y, al mismo tiempo, la brillante explicación, respecto del suicidio como posición límite, de Santiago Alba Rico. En su libro ¿Podemos seguir siendo de izquierdas? (Panfleto en sí menor) (2013) Alba Rico se hace la siguiente pregunta:

¿Cual habría sido un comportamiento "de izquierdas" en la balsa de La Medusa? Incluso si entre sus 147 pasajeros se hubiesen encontrado Marx, Engels, Lenin, Rosa Luxemburgo, Gramsci y Fidel Castro y pudiéramos estar seguros de lo que es capaz un cuerpo (...), su decisión sólo tendría que ver con la decencia o la dignidad, valores fundamentales para cualquier proyecto de civilización, pero cuya eclosión - como la de una flor- constituirá siempre una sorpresa o un milagro: sea como fuere, un suicidio altruista o un canibalismo ordenado (las dos últimas opciones soberanas, aunque igualmente irracionales); no podría calificarse "de izquierdas"; y no se podrían calificar así porque también "gente de derechas" puede conducirse de un modo altruista o heroico, sin que ello pruebe ninguna verdad "ideológica", y porque la construcción de un proyecto "de izquierdas" pre supone la existencia de un mundo en el que hay más alternativas que el suicidio y el canibalismo $^{37}$.

La pregunta de Alba Rico no es retórica, compete a los límites de una situación en la que la posición de izquierda, en medio de una inminente proximidad con la muerte, se hace imposible y, entonces; el proyecto civilizatorio se desplaza o queda reducido a la animalidad de ese cuerpo que en la pura necesidad de la sobrevivencia es capaz por desesperación de lanzarse suicidamente al mar o de canibalizar a sus semejantes como ocurrió con la tragedia de la fragata francesa Méduse (1816).

La tragedia de la UP y lo que ocurrió la mañana del 11 de septiembre de 1973 fue un naufragio inducido por la respuesta de la oligarquía y las Fuerzas Armadas y por poderes supranacionales a un proceso de plebeyización de la política. ¿Qué es lo que debe sobrevivir en una situación política límite? Si esa política es la "verdad ideológica" del Bien Común fundado en la traducción moderna y criolla de la UP como el Bien que, por la vía pacífica al socialismo, lo que debía sobrevivir es la creencia en que ese Bien era el socialismo de la dietética de las empanadas y el vino tinto. De manera que, si el suicidio de Allende puede ser tipificado como altruista, según la conceptualización de Durkheim, esto se debe a que el cálculo del "compañero suicida" es prolongar una política de la sobrevivencia que pueda tener efectos de una reminiscencia. Esta es doble y aporética. Por un lado, la reminiscencia de los traidores que destruyeron el proyecto civilizatorio de la dietética socialista y, por

\footnotetext{
S. Alba Rico, ¿Podemos seguir siendo de izquierdas (Panfleto en si menor), Barcelona, Pollen Edicions, 2015, p. 16.
} 
otro, la reminiscencia de esa sociedad civil que quedó trunca, pero que gracias al acto ético heredó la verdad mutilada de los valores irrenunciables de la UP que hizo de la dignidad de las clases trabajadoras su "fuerza de flaquezas" 38 . La reminiscencia de esta herencia, aunque residual, solo puede ocurrir desde la donación que se consuma con el paso al acto. "Uno no sabe lo que puede un cuerpo" y, sin embargo, esa mañana del naufragio anunciado, Allende calcula lo que puede su cuerpo. En el acto ético, el cuerpo debe "transustanciarse" en el espectro de la tragedia política de la UP y transformarse en el agente de un legado en el que las "acciones" e incluso los errores políticos deben quedar subordinados a la potencia del cuerpo del suicida capaz de eclipsar el tiempo de la dictadura como el origen de la sangre de los militares golpistas.

Allende condena a los militares a la desgracia "eterna" de los asesinos sin redención en el tiempo y, a su vez, clausura su impostura de héroes. Una vez que el acto ético se ha consumado Allende ya no es el mismo. El legado de sus discursos y el gesto de un gran estadista deviene elogio de lo plebeyo. Un elogio que si bien no detiene la masacre y el genocidio de la población civil y de los militantes de la UP impide que la tragedia se convierta en una llana victoria de sus enemigos. El acto ético del suicidio es la donación de la vida para prolongar la dignidad de un proyecto civilizatorio moderno y detener una masacre aún mayor que la perpetrada por los 17 años de terror de la dictadura. Si el desenlace hubiese sido la guerra civil probablemente el origen de la sangre de la sociedad neoliberal sería indistinto del de los militares, la derecha y la administración Nixon. No sería posible el enunciado de Bolívar Echeverría que, interpretando la consigna de Rosa Luxemburgo "socialismo o barbarie", piensa que la posición de la izquierda solo tiene sentido en el interior de un programa donde ésta se sustrae de la barbarie de la modernidad capitalista. La izquierda para Echeverría solo puede escapar a la barbarie, es decir, al principio de crueldad que estructura a las sociedades neoliberales si escapa al "sin sentido":

Sólo un hecho impide hablar del siglo XX como de una época de barbarie (...). Se trata de la existencia de la Izquierda: una cierta comunidad de individuos, una cierta fraternidad, a veces compacta, a veces difusa, que ha vivido esa historia bárbara como la negación de otra historia deseada y posible a la que debe accederse mediante la revolución. (...) La existencia de la izquierda le da un sentido - un contra sentido- al sin sentido del siglo $\mathrm{XX}^{39}$.

El acto ético de Allende es el intento más radical de sustraerse al sin sentido de la barbarie. Sin embargo, esta sustracción suele ser negado por el moralismo timorato de la izquierda. El miedo a reconocer que Allende se

38 Este concepto de estirpe benjaminiana ha sido trabajado y elaborado a propósito de la experiencia políticas del 15-M y del primer Podemos en el libro de German Cano Fuerza de flaquezas. Nuevas gramáticas politicas (2015).

39 B. Echeverría, El discurso crítico de Marx, México, Editorial Itaca y Fondo de Cultura Económica, 2017, p. 18. Debo la visibilidad de esta cita a la generosidad de Diana Fuentes, intelectual mexicana miembro de Revista Común y especialista en la obra de Bolívar Echeverría. había suicidado se mezcló durante años con el relato alternativo y militarizado del "compañero presidente" que había caído con un fusil AKA-47 regalado por Fidel Castro. El relato de ese Allende disparando desde una de las ventanas de La Moneda alimentó durante los años de la resistencia a Pinochet el imaginario de la lucha armada. Esto no deja de ser un episodio ínfimo respecto de la fidelidad de Allende a la vía pacífica al socialismo. El Allende militarizado nunca existió, o si lo hizo fue en la fantasía de los que intentaron organizar la lucha armada contra la dictadura y la consumación del principio de crueldad del liberalismo extremo. De acuerdo con la pregunta del libro mencionado de Alba Rico y a la certeza de Echeverría de que el siglo XX hubiese sido la pura barbarie consumada sin esa comunidad que la ha negado o, como preferimos decir, que se ha sustraído a la crueldad del sin sentido, podemos afirmar que la experiencia de la UP y Allende son la última topología de la comunidad de esa izquierda que se restó al principio de crueldad como configuración de la realidad. Una de las características del principio de crueldad o, más bien, de aquello que está en su base es la militarización de la política. La militarización de la política anula la orientación de esta con respecto al Bien Común. Al no haber política o al estar anulada, la militarización privilegia la inminencia del "estado de naturaleza hobbesiano" en que todos y todas pueden ser potencialmente devorados como lobos o canibalizados por la ausencia de un programa civilizatorio. La militarización de la política o necropolítica es un estado de pura inminencia como gobierno a través de y por la muerte ${ }^{40}$. El paso al acto de Allende es la respuesta a la militarización. La izquierda negó el suicidio porque el relato que se desprende del acto ético no pudo ser capitalizado para organizar una revolución armada contra la dictadura después del golpe de 1973 y tampoco fue de "utilidad" para los partidos de la llamada transición (1989-2019). Estos privilegiaron una política de consenso y pactos fundada en la presencia absoluta de enclaves de poder militarizados y de anulación de la política orientada a un programa civilizatorio.

Allende no era un pastor ni un apóstol, sino un militante político que quiso evitar que la "felonía y la traición" consumaran la guerra civil. El acto altruista y sacrificial desea provocar un efecto en sus enemigos y, así, evitar que la confianza en las posibilidades del Bien Común perdurara en la "conciencia de miles y miles de chilenos". Mientras el palacio de la Moneda arde en llamas, el presidente de la República de Chile habla por radio Magallanes: "Estas son mis últimas palabras y tengo la certeza de que mi sacrificio no será en vano, tengo la certeza de que, por lo menos, será una lección moral que castigará la felonía, la cobardía y la traición". El suicidio es el último recurso contra el método del sin sentido y de la barbarie. El paso al acto desea preservar la hipótesis de que es posible y necesaria la vía pacífica como aquello que se opone a la militarización y la crueldad. Por eso, Allende no acepta rendirse, no acepta

40 La dictadura militar nunca fue un Estado de excepción como han interpretado algunos agambenianos. Por el contrario, el Estado militarizado y genocida del General Augusto Pinochet era la ausencia de todo Estado de derechos. El principio de crueldad fue el dispositivo que articuló el terrorismo, la tortura y la violación sistemática a los Derechos Humanos desde 1973 a 1989. 
hundir la dignidad del experimento popular ante un enemigo injusto. El rechazo motiva el acto que lo convertirá en el mito de la izquierda latinoamericana moderna en el que, a lo largo de la historia, como en los temas borgeanos, habrá un traidor y un héroe. El suicidio es altruista y la tragedia política es moderna. El acto conlleva el intento de interrumpir la guerra y dejar que los traidores y los cobardes consagren un golpe de Estado ya consumado. El castigo está movilizado por el hombre que juró que "respetaría la ley y la constitución" y así lo hizo. Su último acto es un sacrificio que persigue la sanción ética en el interior de una tragedia épica más o menos anunciada en las propias líneas de sus discursos ${ }^{41}$.

El exilio no hubiese tenido el mismo efecto. Allende no regresa como regresa el General Perón o, recientemente, Evo Morales. El paradigma del exilio no es una opción y, así, el acto ético es perfecto; no tiene retorno a través del cuerpo individual. Su retorno solo puede ser mitológico, es decir, solo puede volver desde la espectralidad del fantasma que acecha la posibilidad o la imposibilidad de que el acto ético prolongue la esperanza en la vía pacífica al socialismo. Uno de los pocos intelectuales que entiende la lógica del suicidio y reconoce el acto ético del "compañero presidente" es Moulian. En Conversación interrumpida (1998) nos dice: "Allende opta por una muerte intencional después de haber salido ileso del combate, sin que le hiciera blanco la metralla salpicada por los tanques y por el bombardeo de la Moneda. El suicidio de Allende fue un acto de combate. El presidente pasó en esa terrible mañana del 11 de septiembre de 1973 del dolor a la lucidez"42. El análisis de Moulian percibe que el acto de combate es posibilitado por la lucidez de la donación. Se trata de la lucidez que hace posible una especie de "renacimiento" en el que Allende ingresa por la vía de una transustanciación profana en la lógica del mito del presidente plebeyo. El acto de combate eleva a Allende a casi un personaje épico, una leyenda mítica, que condena a los golpistas a la dialéctica del traidor y del héroe. Por eso, Moulian dirá que Allende "consigue el dominio ascético de sí y ante el escenario de su sobrevivencia a los bombardeos, busca conseguir el mayor efecto histórico. Descarta el exilio y prepara la respuesta más adecuada. Esa respuesta es el gesto del suicidio. Este acto enaltece al que da vida y mancha para siempre a Pinochet" ${ }^{\prime 3}$. Mientras el traidor se convierte en el dictador que después de su detención en Londres (1998), por orden del juez español Baltasar Garzón, muere acusado de robo y malversación de fondos en la placidez de su hogar, Allende entra en la historia como el héroe de una derrota injusta y criminal $^{44}$.

${ }^{41}$ Cf. la compilación de los discursos de Allende de Hugo Latorre Cabal, El pensamiento de Salvador Allende, México, Fondo de Cultura Económica, 1974.

42 T. Moulian, Conversación interrumpida con Allende, Santiago de Chile, LOM Ediciones, 1998, p. 116.

43 Idem.

44 El juicio a Pinochet fue documentado en el film de Patricio Guzmán El caso Pinochet (2001). Guzmán -conocido por haber filmado la experiencia de la UP en el histórico documental La batalla de Chile: Historia de un pueblo sin armas - narra la detención de los 503 días del dictador acusado de genocidio, terrorismo y tortura localizando la cámara en el relato de las mujeres, víctimas de la crueldad del golpe de 1973 .
Así, el último acto de combate marca y mancha. Por un lado, mancha la ignominiosa traición del General Pinochet condenándolo a la historia de la infamia. Y, por otro lado, marca la posibilidad de prolongar la vida de la experiencia popular desde el renacimiento de una subjetividad que hereda la historia de la resistencia y el combate en La Moneda en el acto ético del "compañero presidente". Sin embargo, la épica moderna del combate de Allende no va a redimir a la política plebeya de la UP. La UP es el experimento que queda -como remanente residual y traumático- en el principio subjetivo de los militantes de izquierda. Y, no hay duda, el acto ético castiga, como el propio Allende lo dice, "la felonía y la traición" a las leyes constitucionales de la república. Pero el acto en sí es incapaz de redimir la experiencia plebeya de los tres años de experiencia popular. Allende no era un Mesías. No encarnaba al Moisés de las tablas de las leyes sacras del Estado del bienestar-criollo y tampoco era el cristo del socialismo. Lo que profesaba no era una teología de la tierra prometida. Su política electoralista y parlamentaria no estaba fundada en el a priori abstracto de una utopía sin interregno político. Habiendo perdido toda posibilidad de parlamentar y con los aviones de la FACH sobrevolando sus cabezas, el triunfo del golpe era inminente. El suicidio altruista del "compañero presidente", opuesto al egoísmo de la compulsión narcisista del yo individual, es el método que resiste a condición de extremar hasta la muerte los límites finitos del cuerpo. La lucidez de Allende es trascender la finitud del cuerpo individual y prolongar "su trayectoria como gran político realista. Con ese sacrificio [nos dice Moulian] buscó contribuir a revalorizar a la Unidad Popular, ayudando a eliminar los elementos que la distorsionaban. Se puede decir que en gran medida lo consiguió" 45 .

El acto ético de llevar el cuerpo a sus límites para ofrecerlo, donarlo en el espacio sacrificial de La Moneda en llamas es perfecto. Su perfección consiste en que Allende restituye el espíritu del bien común. El acto del presidente de la república trasciende incluso las "distorsiones" propias de la fiesta y del "exceso" de los devenires plebeyos que tomaron lugar en puntos y zonas estratégicas de la producción y de las instituciones republicanas. Por eso dice que su "sacrificio no será en vano" y que espera que las clases trabajadoras "aprovechen la lección". ¿De qué lección habla? No lo sabemos con exactitud. Pero no es arriesgado aventurar la hipótesis de que se trata de la lección del duro aprendizaje en la política de alianzas con los partidos de la burguesía criolla, la oligarquía y los poderes supranacionales que derrotaron el experimento de la vía pacífica al socialismo. Desde el mismo día que el presidente Allende asumió el mandato soberano, la vía electoral-parlamentaria pendió de la fragilidad de una legalidad que en cualquier momento podía ser violada en nombre de la propiedad burguesa y de los intereses de Estados Unidos.

45 T. Moulian, op. cit. 


\section{El ocaso moderno del Bien Común}

En el cuerpo finito de Allende el golpe militar fracasa. El crimen y la fuerza empleada por los militares no puede matar el último hálito de modernidad republicana que hay en la creencia en el socialismo. Allende no puede detener el bombardeo y sus consecuencias, pero en su acto de combate prolonga la dietética de la consigna de construir el "socialismo con empanada y vino tinto". La consigna dietética como herencia no es ni puede ser comprendida en términos militaristas. La dietética de la UP, de la que se ha escrito muy poco o nada, expresa la voluntad soberana del "buen vivir" y el más alto concepto de la política como aquello que es opuesto al sacrificio, precisamente, por concernir al Bien Común. La dietética hace de la política de la UP uno de sus nudos conflictivos con la propiedad burguesa. En el breve periodo del mandato presidencial de Allende, la sacralidad de la propiedad privada y los valores individualistas de la oligarquía nacional fueron desestabilizados. La política desprivatizadora de Allende atormentó con medidas de nacionalización de empresas estratégicas y expropiaciones de tierras a grandes latifundistas. Las clases trabajadoras se radicalizaron tanto en su experiencia de lucha como en las formas de organización y defensa de la producción nacional. El Bien Común alentó los antagonismos y radicalizó el desprecio por los desposeídos. El resultado de este desprecio es el crimen desatado por el golpe y la violencia ejercida contra el cuerpo de los militantes de la UP. El bien común alegorizado en la dietética del socialismo es desplazado por las consignas del fascismo de los sectores golpistas.

La derecha y los militares se ven a sí mismos como salvadores de la comunidad de la propiedad y los privilegios sociales. La consigna de la Junta Militar es la de "salvar la patria contra el comunismo y el cáncer marxista". Pero el acto del último combate de Allende, su ofrenda corporal para preservar el imaginario moderno y republicano del bien común, los hace fracasar. En el último discurso Allende los juzga, "los procesos sociales no se detienen ni con la fuerza ni con el crimen, la historia es nuestra y la hacen los pueblos". El acto ético de quitarse la vida no logra detener la masacre de los militantes de la UP y menos el terror que se prolongará por 17 años, de la Junta Militar y el General Pinochet. El golpe apaga la llama del pacto festivo entre las clases subalternas y el gobierno socialista de Allende. Pero no logra detener lo que el fascismo vio en la metáfora del "erradicar el cáncer marxista". La lucidez no podrá detener el terror de la dictadura. La decisión de suicidarse -acto soberano por excelencia- impide que el aura moderna del bien común sea completamente erradicada. Esto es lo que trasciende a la finitud del cuerpo de Allende.

El argumento del acto ético como lo que transciende la finitud es similar al que toma lugar en la tradición hegeliana de la reflexión de la muerte. El Bien Común como vida del espíritu, e incluso, se puede decir, como aquello que es totalmente opuesto a la ficción del individuo liberal, muere en la desolación narcisista. El individuo afligido y desgarrado es un efecto de la reproducción del orden tensionado por la irreconciliable diferencia moderna en- tre la propiedad privada y el bien común. Esta tensión es constitutiva de los desgarramientos de la intimidad (aunque las dolencias de la subjetividad no se pueden reducir solo a esta diferencia) y de la falta de un mundo de vida en que el bien común regule la coexistencia desde la "vida ética". La vía pacífica al socialismo es la aspiración a la vida ética del bien común y, así, es la aspiración del experimento popular para reconciliar la ficción de la individualidad con la universalidad del bien común. Esto hace que el último acto de combate de Allende pueda ser interpretado desde una especie de sustancia espiritual cuya matriz originó el compromiso del gobierno popular y el de las clases trabajadoras de realizar el imaginario moderno y republicano del Bien Común. El proyecto popular está compuesto de la sustancia plebeya y republicana que Allende espiritualiza con su propia muerte. En el momento del último acto, el espíritu de la experiencia del devenir plebeyo, entrelazado a la modernidad de la idea del socialismo, se condesaba como sustancia en el cuerpo del líder. En el suicidio la sustancia transita del cuerpo finito del presidente y se eleva a la condición aurática de la validez universal del proyecto. El espíritu de la lucha por el socialismo que transforma el mundo de vida desde la potencia social y política del bien común queda inmunizada contra la crueldad de los golpistas. En el tránsito del dolor a la lucidez, lo inmunizado por la ofrenda de muerte es lo público-común, es decir, es aquello que se opone a la privatización del mundo de vida y sobrevive en el aura desprendida de la muerte altruista de Allende.

En efecto, el suicidio altruista no va a detener la articulación del principio de crueldad que movilizará el terror de los militares. El golpe no es solo, como han formulado modernamente los intelectuales de la "postdictadura" en tono apocalíptico, un "golpe a la representación", "un golpe a la palabra", sino sobre todo la emanación de un principio de crueldad que desnaturaliza por completo la función del Estado moderno ${ }^{46}$. Se trata de la sistemática violación de los derechos humanos que formalmente debería estar asegurada por el Estado. La muerte de Allende es la muerte de un proyecto que no solo resistió la modernización privatizadora del capitalismo, sino también la degradación de las condiciones de explotación (poscolonial) y la crueldad hacia las clases más desposeídas. La resistencia a través de la ofrenda de muerte solo puede entenderse desde la finitud de alguien que encarnaba de manera excepcional la sustancia espiritual de la voluntad soberana, del Bien Común. Pero el liderazgo carismático de Allende no es populista y como puede apreciarse, después del golpe, nunca llegó a constituir fenómenos como el peronismo en la Argentina ${ }^{47}$. Allende es un socialista

\footnotetext{
46 La construcción del Estado y sus instituciones en América Latina nunca gozó de fortalezas en el plano de la legitimidad de las leyes. Chile aparecía simplemente como la ilusión de instituciones democráticas fuertes, pero como ya hemos explicado, esta excepcionalidad tenía pies de barro y descansaba en el olvido de la composición histórica de las instituciones castrenses y civiles.

$47 \quad$ Esta es una relación muy poco estudiada. Los estudios comparativos entre el modelo del exilio de Perón como el general que regresa y Allende como el presidente que muere en nombre de la vida constitucional. Es probable que en la diferencia entre el peronismo y el Allendismo se encuentren modelos irreconciliables entre el populismo y el republicanismo socialista. Este tema excede completamente las posibilidades de analizar en este espacio las divergencias o encuentros entre ambas concepciones de la política.
} 
republicano que sacrificó su vida por un legado moderno. Pero el legado del allendismo no tendrá retorno, como veremos, en el sistema de partidos políticos de la izquierda moderna-tradicional. No sería exagerado decir que, como exponente de la modernidad del socialismo criollo, el sacrificio de Allende es hegeliano: en su cuerpo finito se presenta la vida genérica como vida histórica de la experiencia del "pueblo" que materialmente accedió al Estado. Se trata de un pueblo-efecto de la política plebeya y del legado de las ideas modernas que fueron impulsadas por la UP desde el imaginario genérico-común de la justicia social y del Bien como garante de un "universal concreto". Al respecto, José Luis Villacañas explica lo siguiente:

El tránsito a lo universal se produce desde el individuo. La muerte es siempre algo que cada uno realiza desde sí mismo. Por mucho que el individuo se esfuerce en separarse del género lo lleva dentro. La muerte, en cualquier sentido, siempre es el límite de la locura y de la propiedad. Frente a ella y, a través de ella, como fruto objetivo de la comprensión surge el pensar, lo que Hegel llama lo inmortal, la síntesis inequívoca de individuo y universal, matriz de toda otra síntesis posterior que respete la estructura interna del espíritu, incluida aquí la síntesis del Estado ${ }^{48}$.

Si el suicidio de Allende es la posibilidad de un pensamiento político de la materialidad del género, o, mejor aún, de la especie humana como "universal concreto" es, precisamente, porque su acto ético es "un salto de tigre" en el interior de un republicanismo anti-oligárquico. Pero se trata de un tigre que salta acorralado, asediado por el militarismo y las fuerzas supranacionales que lo derrocan sin miramientos. De manera que el salto solo logra una frágil restitución de la universalidad del imaginario emancipador de la modernidad. El socialismo republicano de Allende no logra ninguna síntesis con el Estado y menos aún consolidar el Estado integral gramsciano. Por el contrario, la unidad contradictoria entre el espíritu del común y el Estado es desgarrada por el poder de la derecha, de los militares y de la conspiración orquestada desde Washington. No hay duda, lo que ocurrió durante los mil días de gobierno popular fue un acontecimiento que desbordó las abstracciones retóricas de la democracia republicana y postcolonial. El acto ético de Allende trasciende la tragedia desde el clamor de una "justicia eterna" y, no obstante, el acontecimiento de la experiencia popular que accedió y desbordó la universalidad abstracta de la democracia liberal-parlamentaria se agota y cierra el umbral de una soberanía plebeya. El golpe y su crueldad se encargará de cerrar el umbral abierto por la energía de la UP y provocará el agotamiento del Estado como síntesis entre las clases subalternas y el Estado-nación.

El acto ético de Allende no disuelve la comunidad nacional, lo hace la dictadura. Ésta cierra todo umbral de mundo de vida articulado por el principio moderno y republicano de la democracia popular. La fidelidad a este principio la había enunciado en el Discurso Inaugural de

48 J. L. Villacañas, La filosofía del Idealismo Alemán. Volumen II. La hegemonía del pensamiento de Hegel, Madrid, Editorial Síntesis, 2001, p. 22. su mandato 5 de noviembre de 1970: "Nuestro programa de gobierno, refrendado por el pueblo, es muy explícito en que nuestra democracia será tanto más real cuanto más popular; tanto más fortalecedora de las libertades humanas, cuanto más dirigida por el pueblo mismo"49. El suicidio como último acto de combate impide que el umbral abierto por el acontecimiento de la UP sea completamente cerrado. El clamor de justicia social en la que anuncia una comunidad porvenir se halla desplegado en la conmovedora sentencia de su último discurso: "sigan sabiendo que, mucho más temprano que tarde, de nuevo se abrirán las grandes alamedas por donde pase el hombre libre para construir una sociedad mejor" ${ }^{\prime 50}$. En esta sentencia acompaña el último acto de combate su insoslayable contenido mesiánico que derrota a los golpistas e impide que el umbral se cierre completamente en la crueldad militar. El acto ético contiene una teoría de la apertura del umbral de pensatividad; es decir, un acto de resistencia que trasciende la inmediatez de su coyuntura. El acto, posibilitado por el paso del dolor a la lucidez, ocurre en el extremo de la profanación del propio cuerpo del presidente que hace imposible una traducción teológica del acto político, interrumpiendo la felonía, la traición y el crimen destinado a ser perfecto por parte de los golpistas y sus secuaces. En el momento en que los golpistas consuman la tragedia política y social de la frágil república de Chile, la dictadura y los poderes supranacionales que la auscultaron serían derrotados. Ni Pinochet ni la administración Nixon serían los salvadores de la nación. El último acto de combate del "compañero presidente" eterniza como traidor al primero y condena el intervencionismo de los segundos a la infamia de ser cómplices de violación de derechos humanos y constitucionales.

¿Qué hay de interesante en esta pequeña pero significativa derrota que Allende le propina a los militares golpistas? En el orden simbólico el acto denunció y permitió la condena de la militarización criminal del golpe y puso en marcha la validez y dignidad de un resto de vida social y política que no se extinguió del todo con la instauración golpista del neoliberalismo. El altruismo de Allende mostró los límites de la democracia burguesa e impidió que el "principio de esperanza" se extinguiera en el oscurantismo del régimen militar. Sin el acto ético de Allende la historia política del neoliberalismo en Chile sería otra. La mañana del 11 de septiembre los golpistas le ofrecieron un avión para sacarlo del país y condenarlo a la humillación del exilio. Allende respondió que "el presidente de Chile no se rinde y solo recibe en La Moneda". En esa negación destinada a la afirmación de la vía parlamentaria al socialismo se le fue trágicamente la vida. Es probable que el "compañero presidente" inaugurara la dimensión de un paradigma trágico de la política cuya modernidad hoy solo sea residual en su posibilidad de enmienda. Es cierto que el restarse a la violencia de armar a los militantes de la UP no evitó la crueldad de los militares. Pero también es cierto que contuvo la guerra

\footnotetext{
49 S. Allende en H. Latorre Cabal, El pensamiento de Salvador Allende, op. cit., p. 111.

50 Ibidem, p. 130.
} 
civil y al mismo tiempo restituyó la lucha de las clases trabajadores y desposeídas a la dignidad de un mundo de vida que pudo haber triunfado.

Allende es un fantasma, es decir, alguien que no está ni vivo ni muerto; su aura fantasmal ha dejado un legado y una herencia que sigue inscrita en el imaginario moderno. La UP es la "superación" de la individualidad de la ideología burguesa y a su vez, el contenido genérico de la vida histórica que tomó lugar en la brevedad de los mil días de gobierno de las clases trabajadoras. La materia plebeya fue su compuesto; es decir, el modo moderno de su composición política fueron las clases subalternas. Estas llegaron a configurar la vida histórica de aquellas tradiciones de lucha que habían sido derrotas en los mil días de gobierno de la UP. Este redimió a los oprimidos por la acumulación de riquezas de los oligopolios de la burguesía nacional y las injusticias de los gobiernos coludidos con la oligarquía financiera. El suicidio altruista del líder de la vía pacífica al socialismo restituye el imaginario moderno del bien común. Esto es lo que permite sostener la hipótesis de que Allende no es solo un ejemplo ejemplar ni el lugar central del paradigma de la derrota. Por el contrario, su supervivencia en el imaginario de las luchas latinoamericanas e incluso su incomodidad para la política contemporánea de las izquierdas tradicionales es su pequeña victoria y no su derrota. No hay ninguna duda de que la experiencia de la UP pervive a través del paradigma de una política trágica y que dicha pervivencia es fuertemente inscrita en el clamor de la justicia social como elemento insoslayable de toda política con pretensiones emancipadoras. En otras palabras, el desprendimiento de la sustancia ética del mundo de vida orientado a la universalidad concreta del bien común es el clamor de justicia. Este clamor de justicia no tiene un verosímil en el retorno de la UP como retorno de lo mismo. El legado de Allende es residual porque se enfrenta a las profundas transformaciones a las que está sometida la vida política de las poblaciones. Por lo mismo, residual también sería hoy el modo en que la política socialista movilizó a importantes sectores de la sociedad civil la confianza en la constitución y las leyes herederas de lo que en América Latina ha sido una "modernidad inacabada", subordinada a los procesos globales de depredación de los mundos de vida posibles e imposibles.

La modernidad plebeya de Allende es heredera de un profundo sentimiento de justicia e igualdad que funcionó como principio de articulación de los valores que inspiraron la corta duración del socialismo con "empanadas y vino tinto". Pero, sobre todo, es heredera de la condensación del tiempo histórico de un principio civilizatorio de modernidad que fue traducido desde una especie de exceso de poder plebeyo respecto del control que las oligarquías nacionales habían tenido sobre la fragilidad de las instituciones republicanas. Es muy probable que la función de liderazgo y el carisma de Allende no tengan retorno en el interior de las instituciones que en Chile son aún más frágiles que aquellas que existían antes del golpe de 1973. Sin embargo, el agotamiento del liderazgo carismático de líderes como Allende no es el ocaso de la imaginación fundada en las nuevas experiencias de lo plebeyo.

\section{Bibliografía}

Abensour, M., La democracia contra el Estado. Marx y el momento maquiaveliano, Madrid, Los libros de la Catarata, 2017.

Alba Rico, S., ¿Podemos seguir siendo de izquierdas (Panfleto en sí menor), Barcelona, Pollen Edicions, 2015.

Altamirano, C., Dialéctica de una derrota, México, Siglo XXI, 1977.

Bengoa, J., Reforma Agraria y revolución campesina: seguido de un homenaje a los campesinos desaparecidos, Santiago de Chile, LOM Ediciones, 2016.

Benjamin, W., Tesis sobre la historia y otros fragmentos. Introducción y traducción de Bolívar Echeverría. Ediciones UACM \& Editorial Itaca, Ciudad de México, 2006.

Cabieses Donoso, M., "Chile: el voto y el fusil”, Punto Final 73, 1969.

Cano, G., Fuerzas de flaqueza: nuevas gramáticas políticas, Madrid, Libros Catarata, 2015.

Cooke, W., "Peronismo y revolución", en F. Martínez Heredia (ed.), La crítica en tiempo de Revolución. Antología de textos de Pensamiento Crítico, Santiago de Cuba, Editorial Oriente, 2010.

Debray, R., Conversaciones con Allende: ¿logrará Chile implantar el socialismo?, México, Siglo XXI, 1975.

Durkheim, E., El suicidio, trad. Sandra Chaparro Martínez, Madrid, Ediciones Akal, 2012.

Echeverría, B., El discurso crítico de Marx, México, Editorial Itaca y Fondo de Cultura Económica, 2017.

Fontana, J., Historia: Análisis del pasado y proyecto social, Barcelona, Crítica, 2013.

Gajic, T., Paradoxes of Stasis. Literature, Politics, and Thought in Francoist Spain, Nebraska, University of Nebraska Press, 2019.

Garcés, J., Allende y la experiencia chilena. Las armas de la política, Barcelona, Ariel, 1976.

Gaudichaud, F., Chile 1970-1973. Mil dias que estremecieron al mundo, Poder popular, cordones industriales y socialismo durante el gobierno de Salvador Allende, Santiago de Chile, LOM Ediciones, 2016.

Gunder Frank, A., Lumpenburguesía: Lumpendesarrollo. Dependencia, clase y politica en Latinoamérica, Buenos Aires, Ediciones Periferia S.R.L., 1973.

Laclau, E. y Chantal M., Hegemonía y estrategia socialista: Hacia una radicalización de la democracia, Madrid, Siglo XXI, 1987.

Latorre Cabal, H., El pensamiento de Salvador Allende, México, Fondo de Cultura Económica, 1974.

Moulian, T., Conversación interrumpida con Allende, Santiago de Chile, LOM Ediciones, 1998.

-, Chile actual. Anatomía de un mito, Santiago de Chile, LOM Ediciones, 1997.

Marchant, P., Escritura y temblor, P. Oyarzún y W. Thayer (eds.), Santiago de Chile, Editorial Cuarto Propio, 2000.

Quijano, A., Antología esencial. De la dependencia histórico-estructural a la colonialidad/descolonialidad del poder, D. Assis Clímaco (sel.), Buenos Aires, CLACSO, 2014. 
Rinesi, E., Política y tragedia. Hamlet, entre Hobbes y Maquiavelo, Buenos Aires, Colihue, 2005.

Salazar, G., La enervante levedad histórica de la Clase Política Civil (Chile, 1900-1973), Santiago de Chile, Debate, 2016.

-, El Ejército de Chile y la soberanía popular, Santiago de Chile, Debate, 2019.

Sollers, P., Sobre el Materialismo: del atomismo a la dialéctica revolucionaria, Valencia, Pre-Textos, 1979.

Traverso, E., Left-Wing Melancholia: Marxism, History, and Memory, New York, Columbia University Press, 2021.

Urbano, F., El puño fragmentado: la subjetividad militante de la izquierda en el Chile post-dictatorial, Concepción, Ediciones Escaparate, 2008.

Villacañas, J. L., La filosofía del Idealismo Alemán. Volumen II. La hegemonía del pensamiento de Hegel, Madrid, Editorial Síntesis, 2001.

Zupančič, A., Ethics of the real. Kant, Lacan, London, Verso, 2000. 